\title{
Synthesis, Spectral Characterization and Thermal Behavior of Newly Derived La(III), Co(III) and Mn(II) Complexes with Schiff Base Derived from Methionine and Salicylaldehyde
}

\author{
Shariful Islam, A. K. M. Nur Alam Siddiki, Shahida Begum, Md. Abdus Salam* \\ Department of Chemistry, Faculty of Science, University of Dhaka, Dhaka, Bangladesh \\ Email: *masalam@du.ac.bd
}

How to cite this paper: Islam, S., Siddiki, A.K.M. Nur Alam, Begum, S. and Salam, Md.A. (2018) Synthesis, Spectral Characterization and Thermal Behavior of Newly Derived $\mathrm{La}$ (III), Co(III) and $\mathrm{Mn}$ (II) Complexes with Schiff Base Derived from Methionine and Salicylaldehyde. Open Journal of Inorganic Chemistry, 8, 55-69.

https://doi.org/10.4236/ojic.2018.82005

Received: August 8, 2017

Accepted: March 27, 2018

Published: March 30, 2018

Copyright $\odot 2018$ by authors and Scientific Research Publishing Inc. This work is licensed under the Creative Commons Attribution International License (CC BY 4.0).

http://creativecommons.org/licenses/by/4.0/

\section{(c) (i) Open Access}

\begin{abstract}
Many metal complexes of Schiff base derived from different amino acids are widely employed as biologically active materials, especially as antibacterial agents. Three new metal [Co(III), $\mathrm{Mn}(\mathrm{II})$ and $\mathrm{La}(\mathrm{III})]$ complexes with the Schiff base (L) derived from salicylaldehyde and amino acid (methionine) were synthesized and investigated by using various physico-chemical techniques such as elemental analysis, FTIR, UV-visible spectroscopy, magnetic measurement, thermo gravimetric analysis (TGA) and X-ray powder diffraction (XRD) method. From spectral studies, it has been concluded that the synthesized ligand acts as a tetra-dentate molecule, coordinates metal through azomethine nitrogen, sulfur, phenolic oxygen and carboxylate oxygen. UV-visible spectrophotometry showed the characteristic absorption bands corresponding to a square planar geometry for $\mathrm{La}(\mathrm{III})$ and $\mathrm{Mn}$ (II) metal complexes and tetrahedral geometry for Co(III) complex. The XRD data demonstrated that the manganese and cobalt complexes were crystalline but the lanthanum complex was amorphous in nature. The empirical formula of the synthesized complexes based on analytical data were $\left[\mathrm{Co}\left(\mathrm{C}_{12} \mathrm{H}_{13} \mathrm{SNO}_{3}\right)\right]$ $\left(\mathrm{NO}_{3}\right),\left[\mathrm{La}\left(\mathrm{C}_{12} \mathrm{H}_{13} \mathrm{SNO}_{3}\right)\right](\mathrm{Cl})\left(\mathrm{H}_{2} \mathrm{O}\right)$ and $\left[\mathrm{Mn}\left(\mathrm{C}_{12} \mathrm{H}_{13} \mathrm{SNO}_{3}\right)\right]$.
\end{abstract}

\section{Keywords}

Schiff Base, Metal Complexes, Spectral Studies, Thermal Behavior, X-Ray Powder Diffraction

\section{Introduction}

Schiff bases (also known as imine or azomethine) and their complexes are syn- 
thesized from the condensation of an amino compound with carbonyl compounds under specific conditions. They exhibit a broad range of biological activities including antifungal, anti-bacterial, antimalarial, anti-proliferative, anti-inflammatory, antiviral, antipyretic properties and extensively used for industrial purposes [1]-[6]. A number of Schiff base complexes exhibit excellent catalytic activity in a wide range of chemical reactions both in homogeneous and heterogeneous catalysis [7]. Over the past few years, there have been many reports on their applications as catalyst in several reactions such as polymerization reaction, reduction of thionyl chloride, oxidation of organic compounds, reduction reaction of ketones, aldol reaction, Henry reaction, epoxidation of alkenes, hydrosilylation of ketones, synthesis of bis(indolyl) methanes and DielseAlder reaction [8]-[14]. Structurally, a Schiff base is a nitrogen analogue of an aldehyde or ketone in which the carbonyl group (CO) has been replaced by an imine or azo-methine group, as shown in Figure 1 [15] [16] [17] [18].

Methionine[2-amino-4-(methylthio) butanoic acid] is an essential amino acid that is used in the biosynthesis of proteins. It contains an $\alpha$-amino group (which is in the protonated $-\mathrm{NH}_{3}^{+}$form under biological conditions), an $\alpha$-carboxylic acid group (which is in the deprotonated $-\mathrm{COO}^{-}$form under biological conditions), and an S-methylthio ether side chain, classifying it as a nonpolar, aliphatic amino acid. Methionine is a bipodal ligand which has greater interest in coordination chemistry, as shown in Figure 2(a). Salicylaldehyde (2-hydroxybenzaldehyde) is the organic compound with the formula $\mathrm{C}_{6} \mathrm{H}_{4} \mathrm{CHO}-2-\mathrm{OH}$. Salicylaldehyde is a key precursor to a variety chelating agents, some of which are commercially important, as shown in Figure 2(b). Schiff base ligands can form very stable complexes compare to some other ligands, as shown in Figure 2(c) [19] [20] [21].

\section{Experimental}

\section{Chemicals and Instruments}

All chemicals used were of analytical grade (AR) and of the highest purity

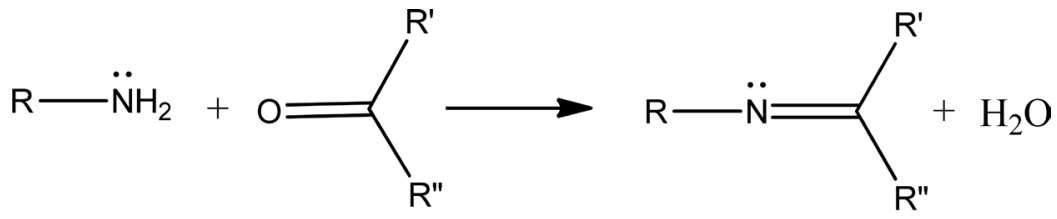

$1^{0}$ amine

aldehyde or ketone

Schiff base

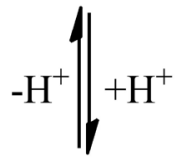

protonated Schiff base

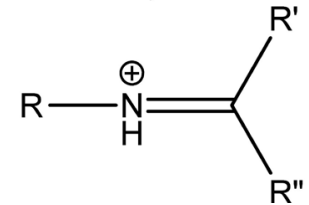

Figure 1. General scheme for formation of Schiff bases. 
<smiles>CSCCC(N)C(=O)O</smiles>

(a)<smiles>O=Cc1ccccc1O</smiles>

(b)<smiles>CSCCC(/N=C/c1ccccc1[O-])C(=O)[O-]</smiles>

(c)

Figure 2. Chemical structure of methionine (a) salicyldehyde (b) and Schiff base (c).

available. Salicylaldehyde and methionine (Sigma-Aldrich, Germany) were used to prepare the Schiff base that was mixed with (each) Mn(II) chloride tetrahydrate, La(III) chloride hexahydrate and Co(III) nitrate hexahydrate (Merck, Germany) in order to synthesize their complexes. The organic solvents used included methanol, ethanol, chloroform, acetone and DMSO. These solvents were either spectroscopically pure from Merck, Germany or purified by the recommended methods and tested for their spectral purity.

Percentage of carbon, hydrogen, sulfur and nitrogen present in the complex were recorded in a CHNS elemental analyzer (VARIO-MICRO V1.6.1, GmbH, Germany). Melting points of the studied compounds were taken in a melting points apparatus (SMP 11, Stuart, England), which have the capacity of recording the temperature up to $350^{\circ} \mathrm{C}$. Infrared spectra of the compounds were recorded in a FTIR spectrophotometer (IRPrestige-21, Shimadzu, Japan) in the range of $400-4000 \mathrm{~cm}^{-1}$ using $\mathrm{KBr}$ pellets. Ultraviolet-visible spectral analysis was carried out at room temperature in dimethyl sulfoxide (DMSO) in a double beam Shimadzu UV-visible spectrophotometer, model UV-1650 PC. Magnetic susceptibility of the complexes were determined using SHERWOOD SCIENTIFIC Magnetic Susceptibility Balance, Cambridge, England, and Model Magway MSB Mk1. Thermo gravimetric analysis of the complexes was performed in nitrogen atmosphere, using a TGA-50 analyzer, Shimadzu, Japan.

\section{Synthesis of the Schiff base ligand (L)}

Methionine-salicyldehyde Schiff base was synthesized from $10 \mathrm{~mL}$ water containing $0.1497 \mathrm{~g}\left(1 \times 10^{-3} \mathrm{M}\right)$ methionine and $20 \mathrm{~mL}$ ethanol that had been dissolved in advance $0.1209 \mathrm{~g}\left(1 \times 10^{-3} \mathrm{M}\right)$ salicylaldehyde. In order to maintain the $p H$ value 9.0 of the mixture, $1 \times 10^{-3} \mathrm{M} \mathrm{NaOH}$ solution was added and the mixture was refluxed for 2 hours. The reaction is clarified in Figure 3:

\section{Synthesis of the metal complexes (ML)}

The metal complexes were synthesized in the same manner by mixing $1 \times 10^{-3}$ $\mathrm{M}$ ethanolic solution $(20 \mathrm{~mL})$ of methionine-salicylaldehyde Schiff base with 20 
$\mathrm{mL}$ ethanol containing $\mathrm{Co}\left(\mathrm{NO}_{3}\right)_{3} \cdot 6 \mathrm{H}_{2} \mathrm{O}\left(1 \times 10^{-3} \mathrm{M}\right)$ or $\mathrm{LaCl}_{3} \cdot 6 \mathrm{H}_{2} \mathrm{O}\left(1 \times 10^{-3} \mathrm{M}\right)$ or $\mathrm{MnCl}_{2} \cdot 4 \mathrm{H}_{2} \mathrm{O}\left(1 \times 10^{-3} \mathrm{M}\right)$. Then the mixtures were refluxed for 4 hours. Finally, the volume of solutions was reduced and in all cases, an occurrence of colored precipitate was observed this being assigned to $\mathrm{Co}$ (III) complex or $\mathrm{Mn}(\mathrm{II})$ complex or $\mathrm{La}(\mathrm{III})$ complex respectively. It was filtered, washed with water and dried at room temperature. The reaction is clarified in Figure 4.

\section{Results and Discussion}

The Schiff base ligand was synthesized by refluxing the appropriate amount of methionine with salicylaldehyde in mixed medium (water-ethanol). The metal complexes of Schiff base ligand were prepared by the stoichiometric reaction of the corresponding metal(II) chloride, metal(III) nitrate and metal(III)chloride with the ligand in a molar ratio of 1:1. The complexes were obtained as air-stable solids, which are insoluble in water, partially soluble in acetone, methanol, ethanol and soluble in dimethyl sulfoxide (DMSO). The color, elemental analysis data along with some other physical properties of the synthesized complexes are listed in Table 1 [22] [23] [24].

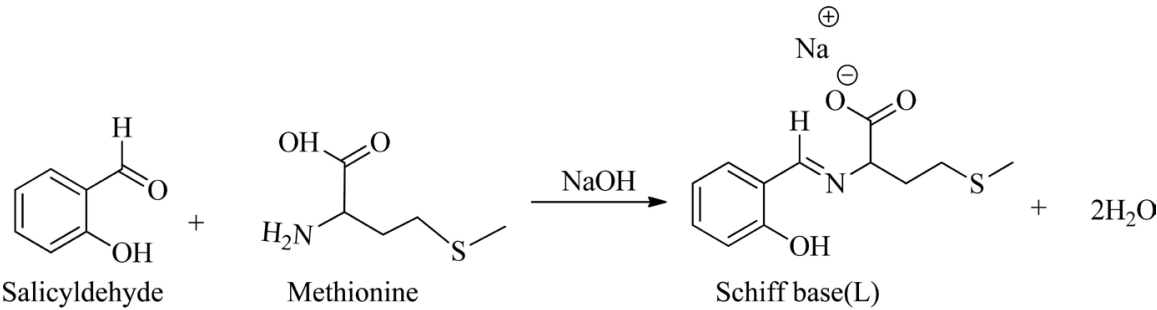

Figure 3. Synthesis route of methionine-salicylaldehyde Schiff base.

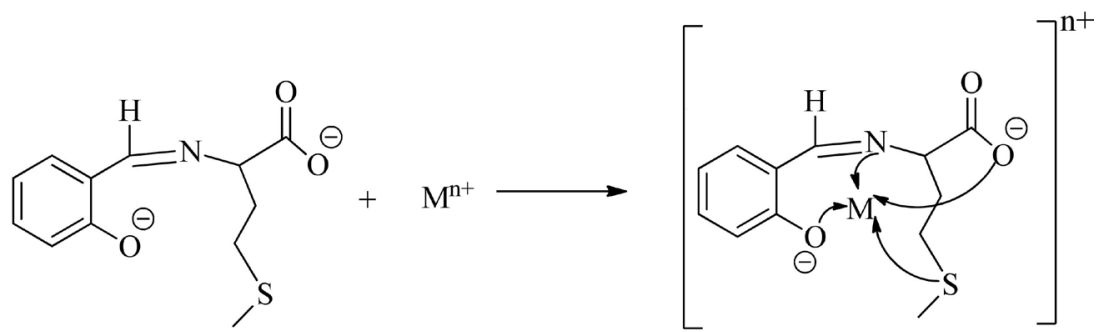

Figure 4. Synthesis route of metal-Schiff base complex.

Table 1. Analytical and physical data of the metal complexes.

\begin{tabular}{|c|c|c|c|c|c|c|c|}
\hline \multirow{2}{*}{$\begin{array}{c}\text { Complex formula } \\
\text { Molecular weight } \\
\text { (g/mol) }\end{array}$} & \multirow[b]{2}{*}{ Color } & \multirow{2}{*}{$\begin{array}{c}\mathrm{m} \cdot \mathrm{p}{ }^{\circ} \mathrm{C} \\
\text { (Decomp.) }\end{array}$} & \multicolumn{5}{|c|}{ Elemental and metal analysis calculated (Found) } \\
\hline & & & $\mathrm{C} \%$ & $\mathrm{H} \%$ & $\mathrm{~N} \%$ & $\mathrm{~S} \%$ & $\mathrm{M} \%$ \\
\hline $\begin{array}{c}{[\mathrm{LaL}]\left(\mathrm{H}_{2} \mathrm{O}\right)(\mathrm{Cl})} \\
443.68\end{array}$ & Yellow & $>340$ & $\begin{array}{c}36.92 \\
(37.42)\end{array}$ & $\begin{array}{c}3.36 \\
(3.98)\end{array}$ & $\begin{array}{c}3.59 \\
(4.07)\end{array}$ & $\begin{array}{c}8.23 \\
(8.67)\end{array}$ & $\begin{array}{c}45.97 \\
(46.30)\end{array}$ \\
\hline $\begin{array}{c}{[\mathrm{CoL}]\left(\mathrm{NO}_{3}\right)} \\
372.24\end{array}$ & Brown & $225-230$ & $\begin{array}{c}46.44 \\
(45.39)\end{array}$ & $\begin{array}{c}4.22 \\
(4.95)\end{array}$ & $\begin{array}{c}4.51 \\
(4.80)\end{array}$ & $\begin{array}{l}10.34 \\
(9.76)\end{array}$ & $\begin{array}{c}34.49 \\
(33.65)\end{array}$ \\
\hline $\begin{array}{l}{[\mathrm{MnL}]} \\
306.24\end{array}$ & $\begin{array}{c}\text { Greenish } \\
\text { yellow }\end{array}$ & $220-226$ & $\begin{array}{c}47.04 \\
(46.83)\end{array}$ & $\begin{array}{c}4.28 \\
(4.88)\end{array}$ & $\begin{array}{c}4.58 \\
(4.87)\end{array}$ & $\begin{array}{c}10.47 \\
(10.02)\end{array}$ & $\begin{array}{c}33.63 \\
(34.56)\end{array}$ \\
\hline
\end{tabular}

Here, $\mathrm{L}=\mathrm{C}_{12} \mathrm{H}_{13} \mathrm{SNO}_{3}$. 


\section{Infra red Spectra}

IR spectra for methionine, Schiff base ligand and metal complexes were recorded in wavenumber range between $400-4000 \mathrm{~cm}^{-1}$. IR spectrum of methionine showed absorption bands at 3000 - 2850, 2800 - 2550, 2106, 1350 - 1000 and $900-690 \mathrm{~cm}^{-1}$ corresponding to $v(\mathrm{~N}-\mathrm{H})$ sym, $v(\mathrm{O}-\mathrm{H})$ carboxylic, $v(\mathrm{~N}-\mathrm{H})$ asym, $\mathrm{v}(\mathrm{C}-\mathrm{N})$ amines and $v(\mathrm{C}-\mathrm{H})$ bent stretching frequencies, respectively. A comparison of the IR spectra of methionine and Schiff base ligand provides proof of the formation of the Schiff base between methionine and salicylaldehyde. The principal band responsible for this is the new absorption band at $1636 \mathrm{~cm}^{-1}$ attributed to $v(\mathrm{C}=\mathrm{N})$ stretching vibration. The IR spectra of different metal complexes are given bellow Figure 5. The most important absorption bands and their assignments are listed in Table 2.

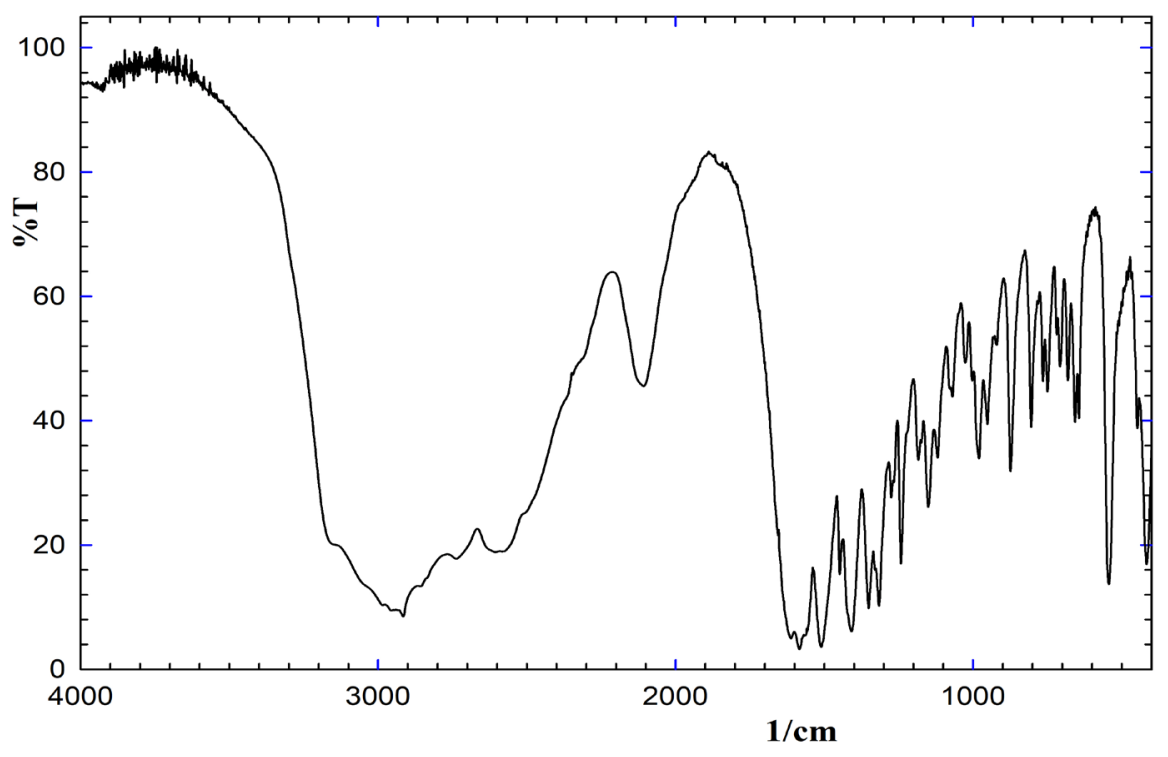

Infrared Spectrum of methionine

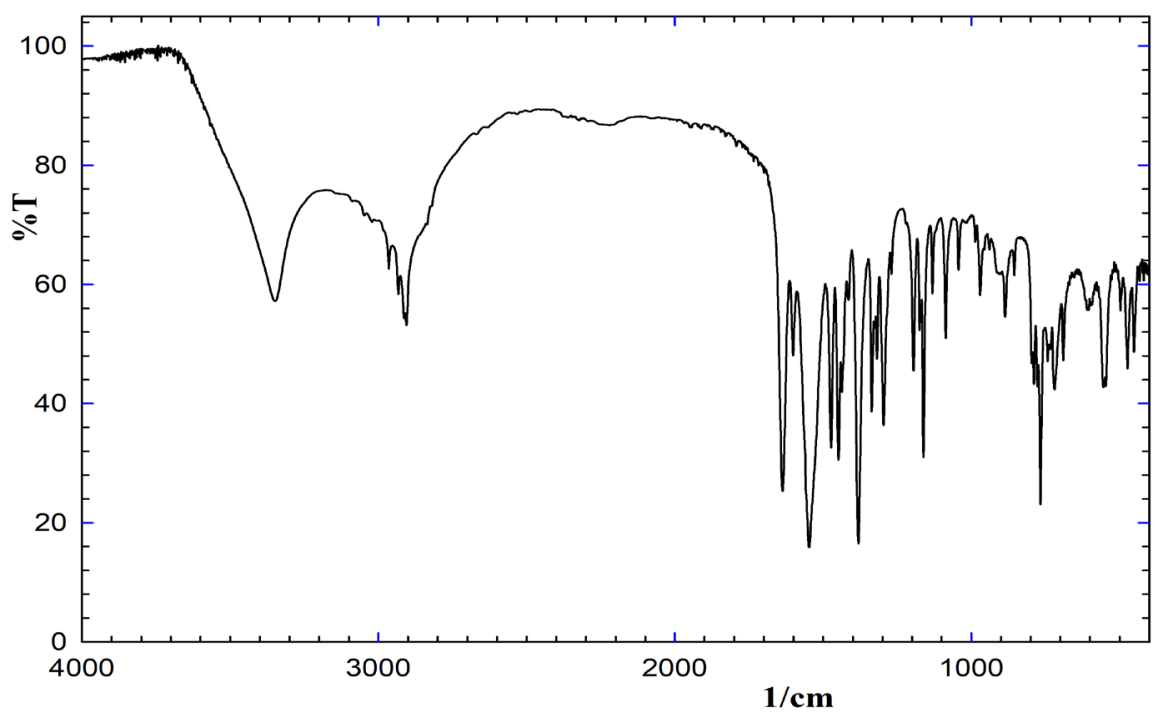

Infrared Spectrum of $\left[\mathrm{Co}\left(\mathrm{C}_{12} \mathrm{H}_{13} \mathrm{SNO}_{3}\right)\right]$ complex 


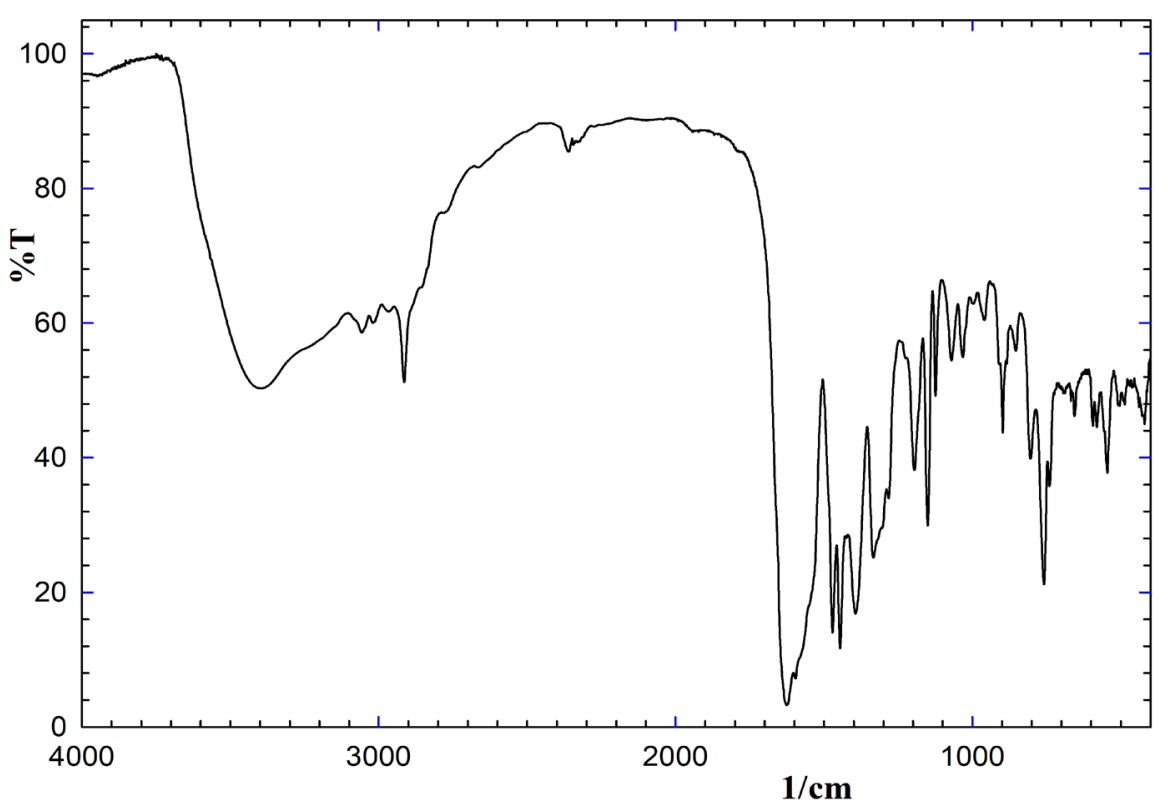

Infrared Spectrum of $\left[\mathrm{La}\left(\mathrm{C}_{12} \mathrm{H}_{13} \mathrm{SNO}_{3}\right)\right]$ complex

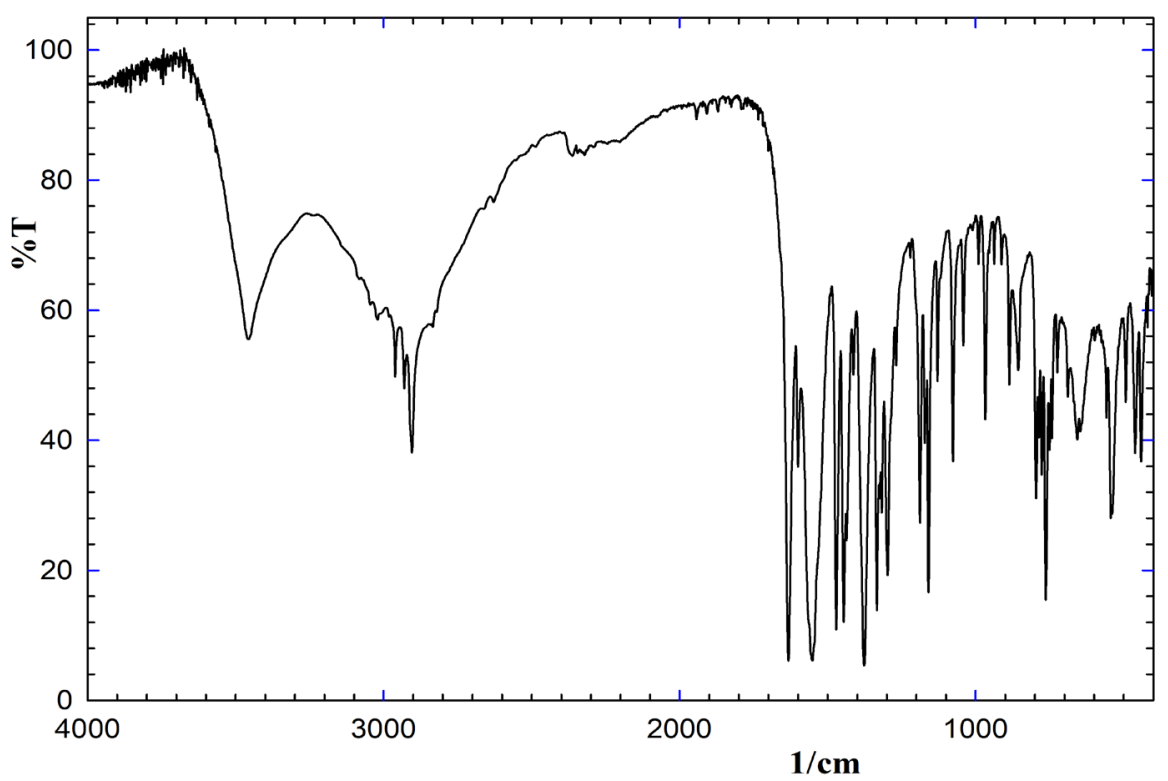

Infrared Spectrum of $\left[\mathrm{Mn}\left(\mathrm{C}_{12} \mathrm{H}_{13} \mathrm{SNO}_{3}\right)\right]$ complex

Figure 5. Infra red spectrum of methionine and metal complexes.

Table 2. Relevant IR data of the Schiff base and its metal complexes $\left(\mathrm{cm}^{-1}\right)$.

\begin{tabular}{ccccccccc}
\hline Compounds & $\mathbf{v}(\mathrm{N}-\mathrm{H})$ & $\mathbf{v}(\mathrm{O}-\mathrm{H})$ & $\mathrm{v}(\mathrm{C}=\mathrm{C})$ & $\mathrm{v}(\mathrm{C}=\mathrm{N})$ & $\mathrm{v}(\mathrm{C}-\mathrm{N})$ & $\mathrm{v}(\mathrm{C}-\mathrm{O})$ & $\mathrm{v}(\mathrm{M}-\mathrm{O})$ & $\mathrm{v}(\mathrm{M}-\mathrm{N})$ \\
\hline Schiff base & $3450 \mathrm{br}$ & - & - & $1636 \mathrm{~m}$ & $1375 \mathrm{~s}$ & $1225 \mathrm{~s}$ & - & - \\
{$[\mathrm{CoL}]\left(\mathrm{NO}_{3}\right)$} & $3348 \mathrm{br}$ & - & $1472 \mathrm{~m}$ & $1640 \mathrm{sh}$ & $1335 \mathrm{~m}$ & $1182 \mathrm{sh}$ & $766 \mathrm{sh}$ & $545 \mathrm{~m}$ \\
{$[\mathrm{LaL}]\left(\mathrm{H}_{2} \mathrm{O}\right) \mathrm{Cl}$} & $3401 \mathrm{br}$ & $2914 \mathrm{~m}$ & $1626 \mathrm{~b}$ & $1645 \mathrm{w}$ & - & $1070 \mathrm{~m}$ & $759 \mathrm{~m}$ & $539 \mathrm{~m}$ \\
{$[\mathrm{MnL}]$} & $3050 \mathrm{br}$ & $3418 \mathrm{~b}$ & $1612 \mathrm{sh}$ & - & $1149 \mathrm{sh}$ & - & $897 \mathrm{~m}$ & $656 \mathrm{~m}$ \\
\hline
\end{tabular}

$\mathrm{Sh}=$ sharp, $\mathrm{m}=$ medium, $\mathrm{br}=$ broad, $\mathrm{w}=$ weak, $\mathrm{s}=$ small. 
The main bands in the IR spectrum of the free Schiff base are at 3450, 1636, 1375 and $1225 \mathrm{~cm}^{-1}$ attributed to $v(\mathrm{OH}), v(\mathrm{C}=\mathrm{N})$ azomethine, $\mathrm{v}(\mathrm{C}-\mathrm{N})$ amine and $v(\mathrm{CO})$ phenolic, respectively [25] [26] [27] [28]. The band at $3450 \mathrm{~cm}^{-1}$ in the ligand spectrum disappears from the complexes as an indicative of phenolic group deprotonation. Instead, the band at $1252 \mathrm{~cm}^{-1}$ assigned to $v(\mathrm{CO})$ phenolic vibration is shifted left in comparison with the ligand, as a result of both deprotonation and coordination of phenolic oxygen. These shifts indicate the participation of the oxygen atom of the deprotonated hydroxyl group which is situated in a favorable position (orto) towards the azomethine group. The spectra of metal complexes exhibited a broad band around $3348 \mathrm{~cm}^{-1}, 3401 \mathrm{~cm}^{-1}$ and 3050 $\mathrm{cm}^{-1}$ which is assigned to different $v(\mathrm{~N}-\mathrm{H})$, associated with the complexes. IR spectra of the ligand presented a band at $1636 \mathrm{~cm}^{-1}$ attributed to $v(\mathrm{C}=\mathrm{N})$ azomethine group, which is shifted to a higher value in two complexes at 1640 and $1645 \mathrm{~cm}^{-1}$ suggesting that the ligand is coordinated to the metal ion through nitrogen atom from azomethine group. The new absorption bands $v(\mathrm{M}-\mathrm{N})$, $v(\mathrm{M}-\mathrm{O})$ and $\mathrm{v}(\mathrm{M}-\mathrm{S})$ observed in spectra of complexes at $545,766,486 \mathrm{~cm}^{-1} ; 539$, $759,416 \mathrm{~cm}^{-1}$ and $656,897,448 \mathrm{~cm}^{-1}$ respectively (see inserted spectrum in Figure 5) shows the coordination of the ligand through nitrogen and oxygen [29] [30]. The IR spectra of the complexes contain several absorption bands from the Schiff base and also new absorption bands, these being attributed to the coordination of the ligand to metal ions through phenolic oxygen atom, carboxylic oxygen atom, sulphur atom and imino nitrogen atom from azomethine bond.

\section{Magnetic measurements and electronic spectra}

The complex $[\mathrm{CoL}]\left(\mathrm{NO}_{3}\right)$ showed $4.59 \mathrm{BM}$, indicated a tetrahedral geometry, which is related to three unpaired electrons. Furtthermore, the square planar geometry of the complex [MnL] showed 5.24 BM which is related to four unpaired electron. On the other hand, square planar complex of $[\mathrm{LaL}]\left(\mathrm{H}_{2} \mathrm{O}\right) \mathrm{Cl}$ have one unpaired electron which showed the magnetic moment $1.47 \mathrm{BM}$, as shown in Table 3.

Electronic spectra of the complexes showed in the Figure 6. The electronic spectra of the cobalt (III) complex exibit one absorption band at $364 \mathrm{~nm}$ which could be assigned ligand to metal charge transfer transition and the other absorption band at $478 \mathrm{~nm}$ corresponds to intra ligand charge transfer transition. These transitions suggest tetrahedral and square planar structure respectively. On the other hand, the lanthanide (III) complex shows absorption band at 362

Table 3. Magnetic moments and electronic spectra of metal complexes.

\begin{tabular}{|c|c|c|c|c|}
\hline Complex & $\mu$ eff. (B.M) & $\lambda_{\max }(\mathrm{nm})$ & Band assignment & Geometry \\
\hline$[\mathrm{CoL}]\left(\mathrm{NO}_{3}\right)$ & 4.59 & $\begin{array}{l}364 \\
478\end{array}$ & $\begin{array}{l}\text { ligant to metal charge transfer } \\
\text { intra ligand charge transfer }\end{array}$ & tetrahedral \\
\hline$[\mathrm{LaL}]\left(\mathrm{H}_{2} \mathrm{O}\right) \mathrm{Cl}$ & 1.47 & $\begin{array}{l}362 \\
480\end{array}$ & $\begin{array}{l}\text { ligand to metal charge transfer } \\
\text { intal ligand charge transfer }\end{array}$ & square planar \\
\hline$[\mathrm{MnL}]$ & 5.24 & 376 & intra liganr charge transfer & square planar \\
\hline
\end{tabular}




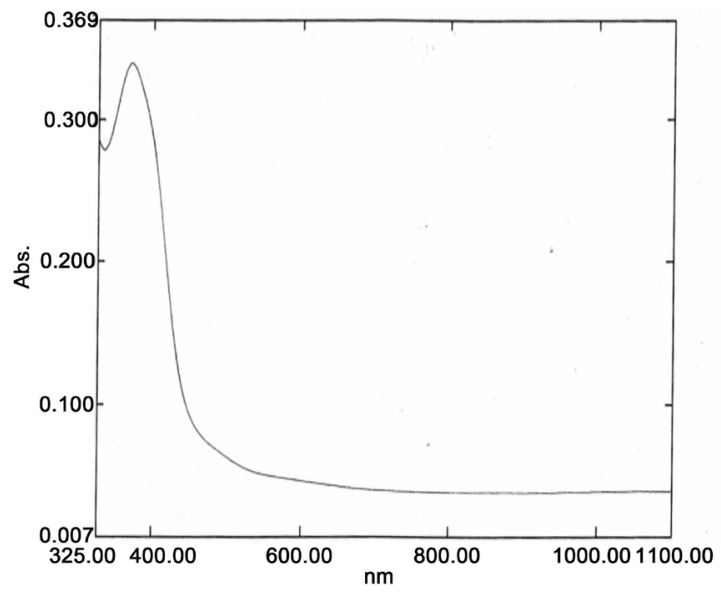

UV-visible spectrum of $0.0005 \mathrm{M}\left[\mathrm{Mn}\left(\mathrm{C}_{12} \mathrm{H}_{13} \mathrm{SNO}_{3}\right)\right]$

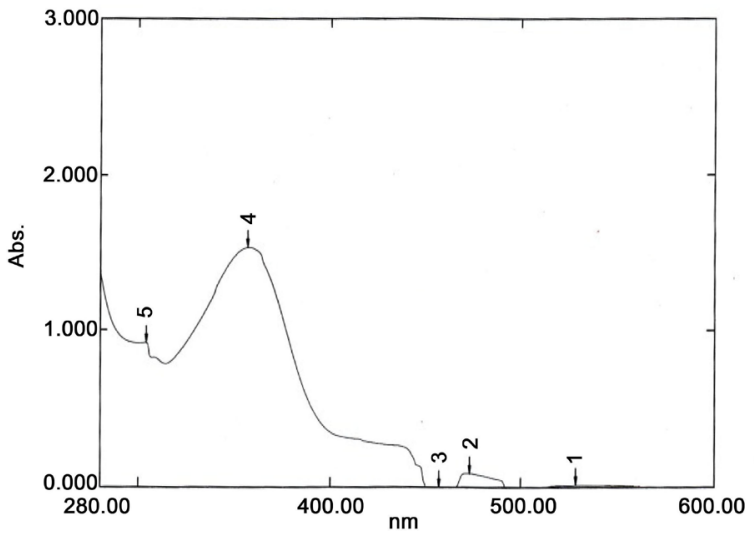

$\mathrm{UV}$-visible spectrum of $0.001 \mathrm{M}\left[\mathrm{La}\left(\mathrm{C}_{12} \mathrm{H}_{13} \mathrm{SNO}_{3}\right)\right](\mathrm{Cl})\left(\mathrm{H}_{2} \mathrm{O}\right)$

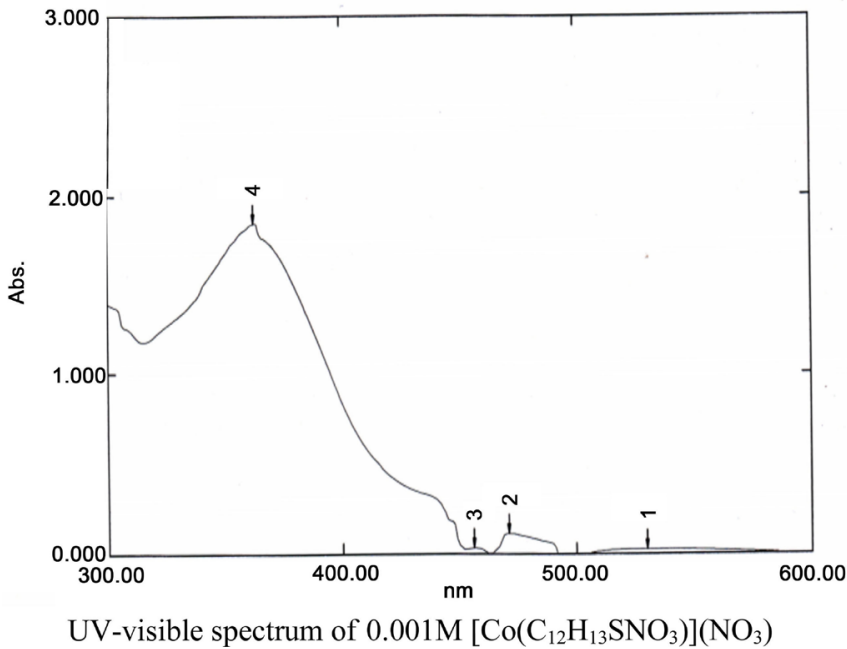

Figure 6. Electronic spectra of the complexes.

$\mathrm{nm}$ and $480 \mathrm{~nm}$ respectively. The intense transition at $362 \mathrm{~nm}$ occur due to the ligand to metal charge transfer transition. The manganese (II) complex shows only one intense absorption band at $376 \mathrm{~nm}$ due to intra ligand charge transfer transition [31]. The electronic spectra of the complexes are agreed with magnetic 
values.

\section{Thermal analysis (TGA)}

Thermogravimetric analysis of the metal complexes are used to: i) get information about the thermal stability of these new complexes,(ii) decide whether the water molecules (if present) are inside or outside the inner coordination sphere of the central metal ion, and iii) suggest a general scheme for thermal decomposition of these complexes [32]. In the present investigation, heating rate were suitably controlled at $10^{\circ} \mathrm{C} \mathrm{min}^{-1}$ under nitrogen atmosphere, and the weight loss was measured from the ambient temperature up to $800^{\circ} \mathrm{C}$. The data are provided in Table 4.

The thermogram of the $[\mathrm{Co}(\mathrm{III}) \mathrm{L}]\left(\mathrm{NO}_{3}\right)$ complex shows three decomposition steps within the temperature range $25^{\circ} \mathrm{C}-800^{\circ} \mathrm{C}$. The first step of decomposition within the temperature range $150^{\circ} \mathrm{C}-320^{\circ} \mathrm{C}$ correspond to the loss of salicylaldehyde molecule with a mass loss of $33.27 \%$ (calc: $39.38 \%$ ). The second step of decomposition within the temperature range $320^{\circ} \mathrm{C}-640^{\circ} \mathrm{C}$ correspond to the loss of methionine molecule with a mass loss of $38.19 \%$ (calc: $39.88 \%$ ). The subsequent step (upto $799^{\circ} \mathrm{C}$ ) correspond to the removal of the organic part of the ligand, leaving metal oxide as a residue. The remaining residue corresponding to a mass of $24.45 \%$ (calc: $23.70 \%$ ).

The thermogram of the $[\mathrm{La}(\mathrm{III}) \mathrm{L}]\left(\mathrm{H}_{2} \mathrm{O}\right) \mathrm{Cl}$ complex shows four decomposition steps within the temperature range $28^{\circ} \mathrm{C}-800^{\circ} \mathrm{C}$. The first step of decomposition within the temperature range $28^{\circ} \mathrm{C}-166^{\circ} \mathrm{C}$ correspond to the loss of water

Table 4. Characteristics of the thermal degradation steps of Co(III), La(III) and $\mathrm{Mn}$ (II) complexes.

\begin{tabular}{|c|c|c|c|c|}
\hline Complex & Step & $\begin{array}{l}\text { Temperature } \\
\text { range } /{ }^{\circ} \mathrm{C}\end{array}$ & Mass loss $/ \%$ & Associated process \\
\hline \multirow{4}{*}[\mathrm{Co}(\mathrm{III})\mathrm{L}]{$\left(\mathrm{NO}_{3}\right)$} & 1 & $150-320$ & 33.27 & loss of salicylaldehyde molecule \\
\hline & 2 & $320-640$ & 38.19 & loss of methionine molecule \\
\hline & 3 & $640-799$ & 2.10 & $\begin{array}{l}\text { gradual loss of mass due to the elimination } \\
\text { of some gases }\end{array}$ \\
\hline & & residue & 24.45 & Cobalt oxide \\
\hline \multirow{5}{*}[\mathrm{La}(\mathrm{III})\mathrm{L}]{$\left(\mathrm{H}_{2} \mathrm{O}\right) \mathrm{Cl}$} & 1 & $28-166$ & 9.14 & loss of one molecule hydrated water \\
\hline & 2 & $166-360$ & 31.11 & loss of methionine molecule \\
\hline & 3 & $360-625$ & 22.67 & loss of salicyldehyde molecule \\
\hline & 4 & $625-799$ & 1.68 & $\begin{array}{l}\text { gradual loss of mass due to the elimination } \\
\text { of some gases }\end{array}$ \\
\hline & & residue & 35.40 & Lanthanum oxide \\
\hline \multirow{4}{*}[\mathrm{Mn}(\mathrm{II})\mathrm{L}]{} & 1 & $166-408$ & 45.96 & loss of methionine molecule \\
\hline & 2 & $408-708$ & 24.66 & loss of salicylaldehyde molecule \\
\hline & 3 & $708-799$ & 3.68 & $\begin{array}{l}\text { gradual loss of mass due to the elimination } \\
\text { of some gases }\end{array}$ \\
\hline & & residue & 23.44 & Manganese oxide \\
\hline
\end{tabular}


molecules of hydration with a mass loss of $9.14 \%$ (calc: $8.40 \%$ ). The second step of decomposition within the temperature range $166^{\circ} \mathrm{C}-360^{\circ} \mathrm{C}$ correspond to the loss of methionine molecule with a mass loss of $31.11 \%$ (calc: $34.90 \%$ ). The third step of decomposition within the temperature range $360^{\circ} \mathrm{C}-625^{\circ} \mathrm{C}$ correspond to the loss of salicyldehyde molecule with a mass loss of $22.67 \%$ (calcd: $29.93 \%$ ). The subsequent step (upto $799^{\circ} \mathrm{C}$ ) correspond to the removal of the organic part of the ligand, leaving metal oxide as a residue. The remaining residue corresponding to a mass of $35.40 \%$ (cala: $36.23 \%$ ).

The thermogram of the $[\mathrm{Mn}(\mathrm{II}) \mathrm{L}]$ complex shows three decomposition steps within the temperature range $31^{\circ} \mathrm{C}-800^{\circ} \mathrm{C}$. The first step of decomposition within the temperature range $166^{\circ} \mathrm{C}-408^{\circ} \mathrm{C}$ correspond to the loss of methionine molecule with a mass loss of $45.96 \%$ (calc: $43.42 \%$ ). The second step of decomposition within the temperature range $408^{\circ} \mathrm{C}-708^{\circ} \mathrm{C}$ correspond to the loss of salicylaldehyde molecule with a mass loss of $24.66 \%$ (calc: $35.56 \%$ ). The subsequent step (upto $799^{\circ} \mathrm{C}$ ) correspond to the removal of the organic part of the ligand, leaving metal oxide as a residue. The remaining residue corresponding to a mass of $23.44 \%$ (cala: $25.30 \%$ ).

\section{X-ray Powder Diffraction (XRD)}

$\mathrm{X}$-ray powder diffraction (XRD) is a rapid analytical technique primarily used for phase identification of a crystalline material and can provide information on unit cell dimensions. The analyzed material is finely ground, homogenized, and average bulk composition is determined. X-ray diffractometers consist of three basic elements: an X-ray tube, a sample holder, and an X-ray detector. $\mathrm{Cu} \mathrm{K} \alpha$ or $\mathrm{Mo} \mathrm{K} \alpha$ radiations are used in the $\mathrm{x}$-ray powder diffractometer. For typical powder patterns, data is collected at $2 \theta$ from $\sim 5^{\circ}$ to $70^{\circ}$, angles that are preset in the X-ray scan. X-ray powder diffraction is most widely used for the identification of unknown crystalline material.

The XRD pattern of different metal complexes is given in Figure 7.

The sharp line diffractogram indicates that $\mathrm{Co}$ (III) and $\mathrm{Mn}$ (II) complexes are crystalline in nature. The XRD pattern of lanthanum complex indicates that it is amorphous in nature.

From literature we know, for body centred crystal $(\mathrm{h}+\mathrm{k}+\mathrm{l}=2 \mathrm{n})$ or the ratio of $\operatorname{Sin} 2 \theta$ must be 2:4:6:8:10:12:14:16:18. The XRD data in Table 5 fulfills the condition. So the structure of the complex $\left[\mathrm{Mn}\left(\mathrm{C}_{12} \mathrm{H}_{13} \mathrm{SNO}_{3}\right)\right]$ and $\left[\mathrm{Co}\left(\mathrm{C}_{12} \mathrm{H}_{13} \mathrm{SNO}_{3}\right)\right]\left(\mathrm{NO}_{3}\right)$ is body centred.

From the result of various studies described and discussed here and the concept of essential criteria of complex formation that the associated ligands must fulfill the coordination number and the oxidation state of the metal ion, the most probable structure of the complexes are given in Figure 8.

\section{Conclusion}

The new $\mathrm{Co}(\mathrm{III}), \mathrm{Mn}$ (II) and $\mathrm{La}(\mathrm{III})$ complexes with the Schiff base derived from methionine and salicylaldehyde were synthesized and characterized. The 

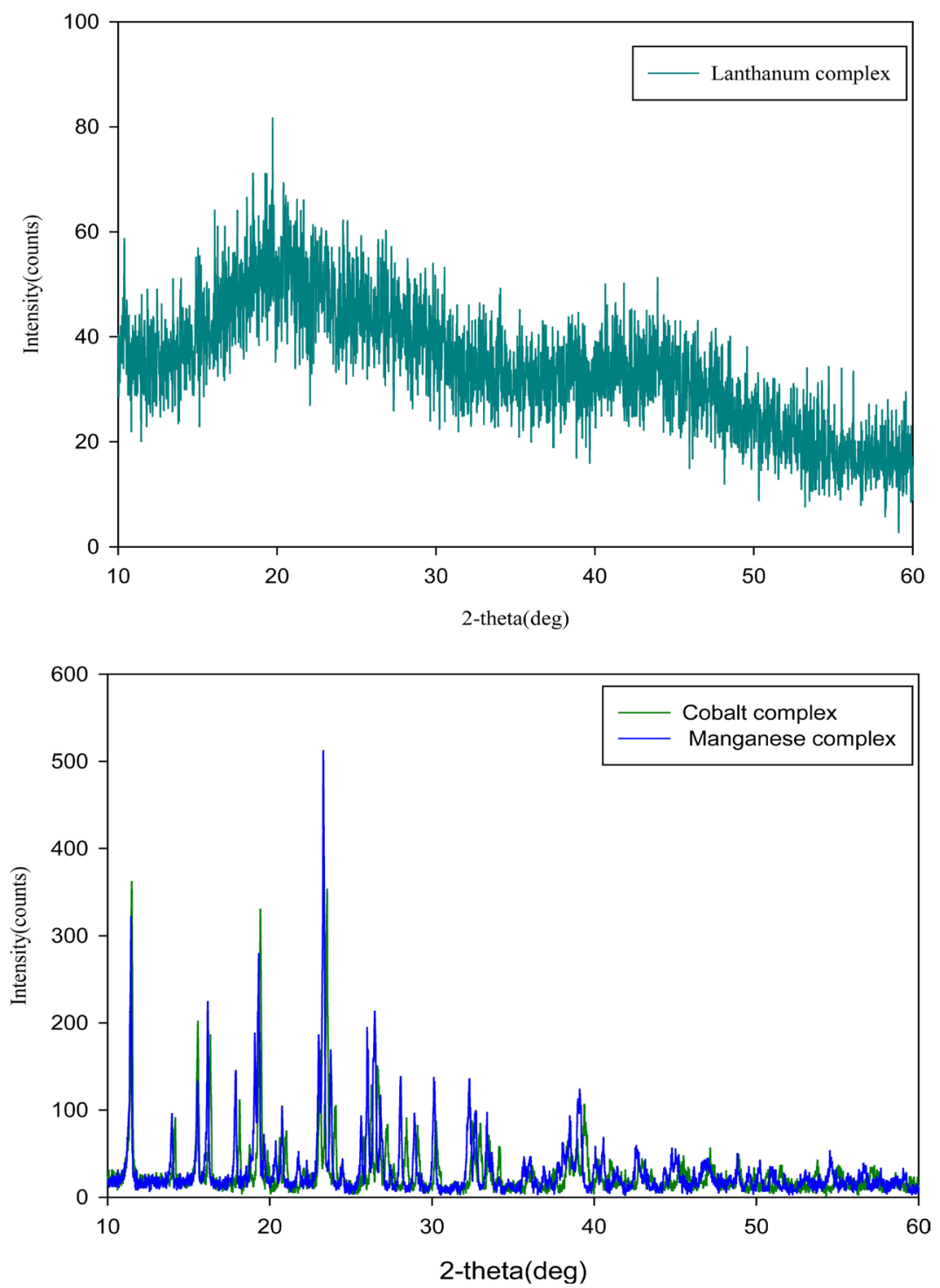

Figure 7. XRD pattern of $\mathrm{Co}(\mathrm{III}), \mathrm{La}(\mathrm{III})$ and $\mathrm{Mn}$ (II) complexes.

Table 5. XRD data of $\left[\mathrm{Mn}\left(\mathrm{C}_{12} \mathrm{H}_{13} \mathrm{SNO}_{3}\right)\right]$ and $\left[\mathrm{Co}\left(\mathrm{C}_{12} \mathrm{H}_{13} \mathrm{SNO}_{3}\right)\right]\left(\mathrm{NO}_{3}\right)$ complexes.

\begin{tabular}{cccccccccc}
\hline $2 \theta$ & $\theta$ & $\operatorname{Sin} 2 \theta$ & $\begin{array}{c}\mathrm{h} 2+\mathrm{k} 2+ \\
\text { 12 or Ratio }\end{array}$ & $2^{*}$ ratio & $2 \theta$ & $\theta$ & $\operatorname{Sin} 2 \theta$ & $\begin{array}{c}\mathrm{h} 2+\mathrm{k} 2+2^{*} \text { ratio } \\
\text { 2 or Ratio }\end{array}$ \\
\hline 11.448 & 5.724 & 0.010 & 1.0 & 2.0 & 11.490 & 5.745 & 0.010 & 1.0 & 2.0 \\
16.179 & 8.090 & 0.020 & 2.0 & 4.0 & 16.339 & 8.169 & 0.020 & 2.0 & 4.0 \\
19.647 & 9.824 & 0.029 & 3.0 & 6.0 & 19.910 & 9.955 & 0.030 & 3.0 & 6.0 \\
23.018 & 11.509 & 0.040 & 4.0 & 8.0 & 23.107 & 11.554 & 0.040 & 4.0 & 8.0 \\
25.611 & 12.809 & 0.049 & 5.0 & 10.0 & 25.790 & 12.895 & 0.050 & 5.0 & 10.0 \\
28.074 & 14.037 & 0.060 & 6.0 & 12.0 & 28.440 & 14.220 & 0.060 & 6.0 & 12.0 \\
30.154 & 15.078 & 0.069 & 7.0 & 14.0 & 30.120 & 15.060 & 0.069 & 7.0 & 14.0 \\
32.640 & 16.320 & 0.079 & 8.0 & 16.0 & 33.003 & 16.502 & 0.080 & 8.0 & 16.0 \\
34.700 & 17.350 & 0.089 & 9.0 & 18.0 & 34.130 & 17.065 & 0.089 & 9.0 & 18.0 \\
\hline
\end{tabular}




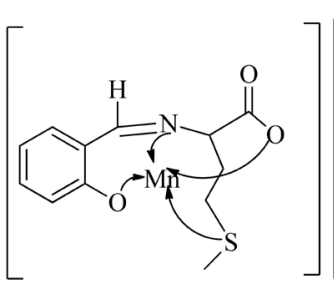

(a)

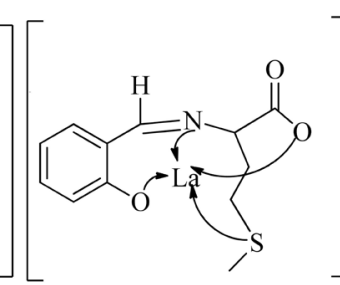

(b)

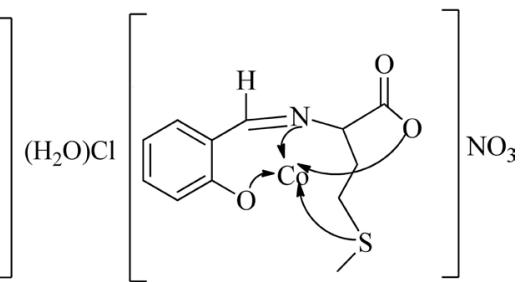

(c)

Figure 8. Probable structure of $\left[\mathrm{Mn}\left(\mathrm{C}_{12} \mathrm{H}_{13} \mathrm{SNO}_{3}\right)\right]$ complex (a), $\left[\mathrm{La}\left(\mathrm{C}_{12} \mathrm{H}_{13} \mathrm{SNO}_{3}\right)\right](\mathrm{Cl})\left(\mathrm{H}_{2} \mathrm{O}\right)$ complex (b) and $\left[\mathrm{Co}\left(\mathrm{C}_{12} \mathrm{H}_{13} \mathrm{SNO}_{3}\right)\right]\left(\mathrm{NO}_{3}\right)$ complex (c).

data collected from IR spectra showed that the Schiff base behaves as a tetra-dentate ligand coordinated in the lanthanum, cobalt and manganese complexes. Electronic spectra and magnetic measurements indicated tetrahedral geometry for the cobalt complex and square planer geometry for lanthanum and manganese complexes. The thermal analysis presented the thermal degradation data of the three complexes. The XRD data revealed that the manganese and cobalt complexes were crystalline whereas the lanthanum complex was amorphous in nature.

\section{References}

[1] Abdel Rahman, L.H., El-Khatib, R.M., Nassr, L.A.E. and Abu-Dief, A.M. (2013) Design, Characterization, Teratogenicity Testing, Antibacterial, Antifungal and DNA Interaction of Few High Spin Fe (II) Schiff Base Amino Acid Complexes. Spectrochimica Acta Part A: Molecular and Biomolecular Spectroscopy, 111, 266-276. https://doi.org/10.1016/j.saa.2013.03.061

[2] Abdel-Rahman, L.H., El-Khatib, R.M., Nassr, L.A.E., Abu-Dief, A.M., Ismael, M. and Seleem, A.A. (2014) Metal Based Pharmacologically Active Agents: Synthesis, Structural Characterization, Molecular Modeling, CT-DNA Binding Studies and In Vitro Antimicrobial Screening of Iron (II) Bromosalicylidene Amino Acid Chelates. Spectrochimica Acta Part A: Molecular and Biomolecular Spectroscopy, 117, 366-378. https://doi.org/10.1016/j.saa.2013.07.056

[3] Abu-Dief, A.M. and Nassr, L.A.E. (2015) Tailoring, Physicochemical Characterization, Antibacterial and DNA Binding Mode Studies of Cu (II) Schiff Bases Amino Acid Bioactive Agents Incorporating 5-Bromo-2-hydroxybenzaldehyde. Journal of the Iranian Chemical Society, 12, 943-955. https://doi.org/10.1007/s13738-014-0557-9

[4] Abdel-Rahman, L.H., Abu-Dief, A.M., El-Khatib, R.M. and Abdel-Fatah, S.M. (2016) Sonochemical Synthesis, DNA Binding, Antimicrobial Evaluation and In $\mathrm{Vi}$ tro Anticancer Activity of Three New Nano-Sized Cu (II), Co (II) and Ni (II) Chelates Based on Tri-Dentate NOO Imine Ligands as Precursors for Metal Oxides. Journal of Photochemistry \& Photobiology, B: Biology, 162, 298-308. https://doi.org/10.1016/j.jphotobiol.2016.06.052

[5] Abdel Rahman, L.H., Abu-Dief, A.M., Ismael, M., Mohamed, M.A.A. and Hashem, N.A. (2016) Synthesis, Structure Elucidation, Biological Screening, Molecular Modeling and DNA Binding of Some Cu (II) Chelates Incorporating Imines Derived from Amino Acids. Journal of Molecular Structure, 1103, 233-244. https://doi.org/10.1016/j.molstruc.2015.09.039

[6] Abdel-Rahman, L.H., Abu-Dief, A.M., Aboelez, M.O. and Abdel-Mawgoud, A.A.H. 
(2017) DNA Interaction, Antimicrobial, Anticancer Activities and Molecular Docking Study of Some New VO (II), Cr (III), Mn (II) and Ni (II) Mononuclear Chelates Encompassing Quaridentate Imine Ligand. Journal of Photochemistry and Photobiology B: Biology, 170, 271-285.

https://doi.org/10.1016/j.jphotobiol.2017.04.003

[7] Abdel-Rahman, L.H., Abu-Dief, A.M., Adam, M.S. and Hamdan, S.K. (2016) Some New Nano-Sized Mononuclear Cu (II) Schiff Base Complexes: Design, Characterization, Molecular Modeling and Catalytic Potentials in Benzyl Alcohol Oxidation. Catalysis Letter, 146, 1373-1396. https://doi.org/10.1007/s10562-016-1755-0

[8] Cukurovali, A., Yilmaz, I., Ozmen, H. and Ahmedzade, M. (2002) Schiff Base Ligands Containing Cyclobutane and Their Metal Complexes with $\mathrm{Co}(\mathrm{II}), \mathrm{Cu}(\mathrm{II})$, $\mathrm{Ni}(\mathrm{II})$ and $\mathrm{Zn}$ (II) Complexes of Two Novel Schiff Base Ligands and Their Antimicrobial Activity. Transition Metal Chemistry, 27, $171 \mathrm{e} 6$.

[9] El-Metwally, N.M., El-Shazly, R.M., Gabr, I.M. and El-Asmy, A.A. (2005) Physical and Spectroscopic Studies on Novel Vanadyl Complexes of Some Substituted Thiosemi-Carbazides. Spectrochimica Acta $(A), 61,1113-1119$.

https://doi.org/10.1016/j.saa.2004.06.027

[10] Cotton, F.A. and Wilkinson, G. (1980) Advanced Inorganic Chemistry, A Comprehensive Text. 4th Edition, John Wiley and Sons, New York, 1310-1344.

[11] Gaballa, A.S., Asker, M.S., Barakat, A.S. and Teleb, S.M. (2007) Synthesis, Characterization and Biological Activity of Some Platinum (II) Complexes with Schiff Bases Derived from Salicylaldehyde, 2-Furaldehyde and Phenylenediamine. Spectrochimica Acta Part A: Molecular and Biomolecular Spectroscopy, 67, 114-121.

[12] Govindarajan, M., Periandy, S. and Carthigayen, K. (2012) FT-IR and FT-Raman Spectra, Thermodynamical Behavior, HOMO and LUMO, UV, NLO Properties, Computed Frequency Estimation Analysis and Electronic Structure Calculations on a Bromotoluene. Spectrochimica Acta, 97, 411-422. https://doi.org/10.1016/j.saa.2012.06.028

[13] Gupta, K.C. and Sutar, A.K. (2008) Catalytic Activity of Schiff Base Complexes. Coordination Chemistry Reviews, 252, 1420-1450.

[14] Ilhan, S., Temel, H., Yilmaz, I. and Sekerci, M. (2007) Synthesis, Structural Characterization and Electrochemical Studies of New Macrocyclic Schiff Base Containing Pyridine Head and Its Metal Complexes. Journal of Organometallic Chemistry, 692, 3855-3865. https://doi.org/10.1016/j.jorganchem.2007.05.031

[15] Joseyphus, R.S. and Nair, M.S. (2010) Synthesis, Characterization and Biological Studies of Some $\mathrm{Co}(\mathrm{II}), \mathrm{Ni}(\mathrm{II})$ and $\mathrm{Cu}(\mathrm{II})$ Complexes Derived from Indole-3-Carboxylate and Glycylglycine as Schiff Base Ligand. Arabian Journal of Chemistry, 3, 195-204. https://doi.org/10.1016/j.arabjc.2010.05.001

[16] Gupta, K.C. and Sutar, A.K. (2008) Catalytic Activities of Schiff Base Transition Metal Complexes. Coordination Chemistry Reviews, 252, 1420-1450.

https://doi.org/10.1016/j.ccr.2007.09.005

[17] Keypour, H., Shayesteh, M., Sharifi-Rad, A., Salehzadeh, S., Khavasi, H. and Valencia, L. (2008) Synthesis and Characterization of Copper (II) and Cobalt (II) Complexes with Two New Potentially Hexadentate Schiff Base Ligands. X-Ray Crystal Structure Determination of One Copper (II) Complex. Journal of Organomettalic Chemistry, 693, 3179-3187. https://doi.org/10.1016/j.jorganchem.2008.07.012

[18] Khalil, S.M.E. (2003) Synthesis, Spectroscopic and Magnetic Studies on Metal Complexes of 5-Methyl-3-(2-Hydroxy-phenyl)Pyrazole. Journal of Coordination Chemistry, 56, 1013-1024. https://doi.org/10.1080/0095897031000135289 
[19] Che, T.-L., Gao, Q.-C., Zhao, J.-S. and Zhang, G. (2008) Synthesis. Structure and Characterization of Schiff Base Metal Complexes and Their Electrochemical Properties of Thionyl Chloride Reduction. Chinese Journal of Chemistry, 26, 1079-1084.

[20] Linert, W. and Taha, A. (1994) Coordination of Solvent Molecules to Square-Planar Mixed-Ligand Nickel (II) Complexes-A Thermodynamic and Quantum-Mechanical Study. Journal of the Chemical Society, Dalton Transactions, 1091-1095. https://doi.org/10.1039/dt9940001091

[21] Yadawe, M.S. and Patil, S.A. (1997) Synthesis, Characterization and Biological Studies of Cobalt (II) and Nickel (II) Complexes with New Schiff Bases. Transition Metal Chemistry, 22, 220-224. https://doi.org/10.1023/A:1018400121316

[22] Parekh, J., Inamdhar, P., Nair, R., Baluja, S. and Chanda, S. (2005) Synthesis and Antibacterial Activity of Some Schiff Bases Derived from 4-Aminobenzoicacid. Journal of the Serbian Chemical Society, 70, 1155-1161. https://doi.org/10.2298/JSC0510155P

[23] Patil, S.S., Thakur, G.A. and Patil, V.R. (2009) Synthesis, Spectral and Biological Studies on Some Mixed Ligand Ni (II) Complexes. Acta Poloniae Pharmaceutica, 66, 271-277.

[24] Selwin Joseyphus, R., Shiju, C., Joseph, J., Justin Dhanaraj, C. and Bright, K.C. (2015) Synthesis and Characterization of Schiff Base Metal Complexes Derived from Imidazole-2-Carboxaldehyde with L-Phenylalanine. Der Pharma Chemica, 7, 265-270.

[25] Abdel-Rahman, L.H., El-Khatib, R.M., Nassr, L.A.E. and Abu-Dief, A.M. (2013) Synthesis, Physicochemical Studies, Embryos Toxicity and DNA Interaction of Some New Iron (II) Schiff Base Amino Acid Complexes. Journal of Molecular Structure, 1040, 9-18. https://doi.org/10.1016/j.molstruc.2013.02.023

[26] Abdel Rahman, L.H., Abu-Dief, A.M., Ali Hashem, N. and Seleem, A.A. (2015) Recent Advances in Synthesis, Characterization and Biological Activity of Nano Sized Schiff Base Amino Acid M (II) Complexes. International Journal of Nanomedicine, 1, 79-95.

[27] Abdel-Rahman, L.H., Abu-Dief, A.M., El-Khatib, R.M. and Abdel-Fatah, S.M. (2016) Some New Nano-Sized Fe (II), Cd (II) and Zn (II) Schiff Base Complexes as Precursor for Metal Oxides: Sonochemical Synthesis, Characterization, DNA Interaction, in Vitro Antimicrobial and Anticancer Activities. Journal of Bioorganic Chemistry, 69, 140-152. https://doi.org/10.1016/j.bioorg.2016.10.009

[28] Abdel-Rahman, L.H., Abu-Dief, A.M., Newair, E.F. and Hamdan, S.K. (2016) Some New Nano-Sized Cr (III), Fe (II), Co (II), and Ni (II) Complexes Incorporating 2-((E)-(pyridine-2-ylimino) methyl) Napthalen-1-ol Ligand: Structural Characterization, Electrochemical, Antioxidant, Antimicrobial, Antiviral Assessment and DNA Interaction. Journal of Photochemistry \& Photobiology, B: Biology, 160, 18-31. https://doi.org/10.1016/j.jphotobiol.2016.03.040

[29] Belghith, S., Chmengui, S. and Hamada, L.B. (2015) Crystal Structure and Physicochemical Properties of a New Tris (2-Amoniumbenzamide) Sulfate $\left(\mathrm{C}_{7} \mathrm{H}_{9} \mathrm{~N}_{2} \mathrm{O}\right)_{3} \mathrm{HSO}_{4} \mathrm{SO}_{4}$. Open Journal of Inorganic Chemistry, 5, 112-121. https://doi.org/10.4236/ojic.2015.54012

[30] Quyoom, S. (2014) Studies of Some Mixed Ligand Ternary Metal Complexes of N Acetyl Cysteine with Zinc (II) and Nickel (II) Metal Ions. Research Journal of Chemical Sciences, 4, 32-35.

[31] Tuncel, M., Ozbulbul, A. and Serin, S. (2008) Synthesis and Characterization of Thermally Stable Schiff Base Polymers and Their Copper (II), Cobalt (II) and Nickel 
(II) Complexes. Reactive \& Functional Polymers, 68, 292-306.

https://doi.org/10.1016/j.reactfunctpolym.2007.08.012

[32] Yousif, E., Muaiad, F. and Adil, H. (2010) Synthesis and Characterization of Fe (II), Mn (II), Co (II), Hg (II) and Cr (III) Complexes of (Benzothiazol-2-ylsulfanyl)Acetic Acid Ligand. Journal of Al Nahrain University, 14, 44-49.

https://doi.org/10.22401/JNUS.14.1.06 